\title{
English Brutes, Eastern Enlightenment
}

\section{Landry}

Donna

What is Enlightenment? What is Enlightenment? What is Enlightenment?

\section{Gender, 44 \\ Caroline Rooney, Decolonising}

"The Ottoman Origins of Modernity" might make Habermas swallow hard, but, follow his arguments about the London coffee house, and that's one place they lead.

\section{Amsterdam," 14}

\section{Steven Shapin, "At the}

"When Animals Attack Capitalists"; I love that.

199

Jonathan Burt, Killing Animals,

"What is Enlightenment?" was once Kant's question, and later Foucault's. As Caroline Rooney suggests in my first epigraph, this is a question that continues to need to be asked, again and again.[1] Among the new configurations of enlightenment within the humanities today are those in which animals mark the spot, refashioning those European Enlightenment grand narratives, the narrative of emancipation and the narrative of progress, with an animal face. This refashioning supplants a putatively human version of the enlightenment, revealing how it might be overlaid with shadowy fellow creatures who, although unacknowledged, have been there all along. The question of fellow and companion species, of creaturely life, opens up new possibilities of engagement. This essay proposes that animal studies, by attending to questions of human-animal reciprocity in the training situation, can shed light on politics at large as well as on cultural politics, while contributing to a less Eurocentric as well as less anthropo-normative cultural history.

A politics of creaturely life can extend even feminist and queer possibilities. Donna Haraway describes animal training "training with an animal" - as "part of disengaging from the 
semiotics and technologies of compulsory reproductive biopolitics," freeing up both human and animal for engaging in something else, elsewhere.[2] For her, queer politics is "at the heart of" dog agility training, in which the "coming into being of something unexpected, ... something not ruled by the logic of the reproduction of the same, is what training with each other is about. ... Training is, or can be, about differences not tamed by taxonomy."[3] Differences not tamed by taxonomy suggests a wild unfolding, what Gayatri Chakravorty Spivak might call "an ab-use (not abuse) of the Enlightenment," "a use from below."[4]

Much recent work, including Haraway's, has emphasized a canine version of humanity's unfolding, shadowing and shadowed by companion species.[5] There is a lot to be said for going to the dogs. This essay, however, offers an equine counterpart. If recent body theory has claimed that "the human body is not simply human," in the Australian sociologist Ann Game's formulation, the new skin-to-skin relationship proposed can just as plausibly be a horse-human one.[6] Game writes: "Putting into question humanist assumptions, I propose that we are always already part horse, and horses, part human; there is no such thing as pure horse or pure human."[7] Lisa Blackman chooses "Becoming (Horse-Human)" to iillustrate the new relationality of body theory, based on the work of Game and of the Belgian philosopher Vinciane Despret, in which "becoming" and "being-with" are forms of horse-human relationship in which mutual transformation occurs.[8]

Despite the highly capitalised world of the equestrian leisure industry, within which this "horses are us" exchange usually takes place, something more to do with free and forward movement, or rambling by the way, and less to do with business as usual, may occur. My third epigraph, from Jonathan Burt's contribution to the conversation that closes the British Animal Studies Group's book Killing Animals - "'When Animals Attack Capitalists!'; I love that" - signalises a certain resistance to the social logic of capital as part of this project too.[9]

Ideas of horse-human connectivity and mutuality are not solely twenty-first century ideas, nor solely European or Anglophone ones. Sir Philip Sidney's Arcadia of 1579-1580 described the ideal relationship between horse and rider as a form of attunement, of 
mutual attention that is also a form of becoming together. Sidney represents the rider as one who is "ever going so just with the horse, either forthright or turning, that it seemed, as he borrowed the horse's body, so he lent the horse his mind."[10] Much has been written about the horse as figuring a certain brute or animal physicality in need of a humanising mind to control it, but that is not quite what Sidney suggests here.[11] His exposition is closer to that of William Cavendish, Duke of Newcastle, whose seventeenth-century treatises continued to be influential well into the eighteenth century. Cavendish explicitly contradicted Descartes's notion that animals could not reason, arguing that horse training was only possible because horses could think and remember:

A horse must be wrought upon more by proper and frequent lessons, than by the heels, that he may know, and even think upon what he ought to do. If he does not think (as the famous philosopher DES CARTES affirms of all beasts) it would be impossible to teach him what he should do. But by the hope of reward, and fear of punishment; and when he has been rewarded or punished, he thinks of it, and retains it in his memory (for memory is thought) and forms a judgment by what is past of what is to come (which again is thought;) insomuch that he obeys his rider not only for fear of correction, but also in hopes of being cherish'd.[12]

Learning more by "lessons" than by the "heels" - more by gentle management than by being kicked on by brutish riders - horses, in Cavendish's system of training, responded better to the promise of affection than to fear of punishment. Cavendish's second wife Margaret, a well-known author in her own right, seconded his representation of himself as a sympathetic horseman who instructed rather than corrected, hoping to inspire obedience rather than exact it. "So great a Love" had he for his horses, she wrote in her Life of her husband, that he refused to part with them even for high prices, and as a consequence, the horses:

had also a particular Love to my Lord; for they seemed to rejoice whensoever he came into the Stables, by their trampling action, and the noise they made; nay, they would go much better in the Mannage, when my Lord was by, then when he was absent; and when he rid them himself, they seemed to take much pleasure and pride in it.[13] 
Thus Cavendish is represented as striving for a working attunement with his horses in which training is not a form of coercion but a kind of wooing.

Thomas Bedingfield went even further in his 1584 translation of Claudio Corte's I/ Cavallenzzo, advising that the highest form of horsemanship was no more and no less than an amatory relationship, in which the rider strove to give pleasure in order to receive it. The practice known as "cherishing" would unfold the closest partnership possible between horse and rider: "But aboue the rest, make him to loue your person, and (as it were) be in loue with you. . . You shall likewise please him much, to cherish him with your hands, when you weare sweete gloues, wiping his face, and chieflie his nostrills with perfumes $\&$ sweet handkerchiefs: for neatnesse \& sweetnes be two things wherein a horsse dooth singularie take pleasure."[14]

Giving horses what they wanted, especially when that something was aesthetic pleasure verging on amorous dalliance, may have arrived in England as an Italian idea, but it was an idea that came originally from further east. As Captain Lewis Edward Nolan declared in the nineteenth century, it was because the Neopolitans and other sixteenth-century Italian riding masters took their example from the Ottomans and other Eastern horsemen that they were the best in early modern Europe. For Nolan, to have been "of Eastern origin" was to have been "doubtlessly good," exercising a kind of horsemanship that bore no relation to later, or other, stiffer, more wooden, and unyielding kinds of European practice.[15]

I have recently argued that nobility and brutality were the defining characteristics of imported equine bloodstock in England during an Eastern invasion on the hoof that largely occurred between 1650 and 1750, simultaneously with Britain's mercantile rise. In this respect the blood horse and the human labourer shared paradoxical discursive space.[16] The dignity of the laborer began to emerge discursively in the eighteenth century - consider Gray's Elegy Written in a Country Church-yard or the vogue for laboring-class poets - and it emerged in tandem with the theorization of political economy and the drive to maximal extraction from land, laborers, and the natural world. The rights of man and the rights of brutes came into being as 
ideas precisely when capitalist productivity and the protoproletarianization of the work force were being consolidated in a Britain newly ambitious of global empire, during the later $1780 \mathrm{~s}$ and 1790s.

The superiority of Eastern horses was seen as representative of the potential superiority of the great Eastern empires and of Islamic culture. There is an important story here about East-West relations.[17] Concepts of the public sphere and of spaces such as coffee houses in which hierarchies of rank might be transgressed, ideas about charitable institutions, and the legislating of religious toleration all had origins in which Britain's relationship with the East, in this case in the form of the Ottoman empire, could be traced.[18] From the late fifteenth through the eighteenth century, within discussions of horsemanship and horse-keeping, a discourse of comparative imperialisms developed, in which the ways Christian Europeans related to their equine charges was contrasted with the ways in which Ottoman and Arab horsemen related to theirs. Westerners frequently reported the "Ieniency" of Eastern treatment of horses and other animals. This closeness and kindness of handlers to their animals was represented in stark contrast to the everyday brutality of European practices.[19] These early commentaries by diplomats, merchants, and travellers pre-dated and perhaps prepared the ground for late eighteenth-century European socalled enlightened views about kindness as opposed to cruelty towards animals.

The Ottoman example also raises questions about the possibility of political negotiations and ethics outside a paradigm of political equality. What might "kindness" or "leniency" mean in a context of a sovereign ruler conceived of as having absolute power, as was the case with the Ottoman sultans? Must Ottoman models of governance be dismissed as unenlightened or as forms of unmitigated political oppression because they presupposed negotiating with and across differences of rank and power as opposed to envisaging an ethos of political equality, the only model of western "enlightened" development? Here debates about the emergence of practical democracy within the public sphere, not necessarily consonant with the theory of democracy, might be usefully articulated with debates about alternative models of political governance. 


\section{What Is Enlightenment? The Romantic Animal}

The rights of man are entangled with the rights of brutes in the later eighteenth century. Debates about the abolition of slavery, the humanity of laborers, the woman question, and political enfranchisement evolve simultaneously in Britain with new attitudes towards animals. Recent work by Ingrid Tague, Christine Kenyon-Jones, and David Perkins suggests that animals did indeed come to enjoy a new status as sentient beings and objects of human sensible affections during the later eighteenth and early nineteenth centuries. For Tague this can be seen most clearly in the case of pets. Tague argues that later eighteenthcentury elegies for pets, in which the satire of previous decades gives way to grief, evoke "the central characteristic of modern pet keeping: the sense of a strong emotional bond between a particular human and a particular animal."[20] According to Tague, a change is marked by the fact that these animals are "praised not for the the work they did while alive but for the emotional satisfaction they provided."[21] This attachment represents the core of Christine Kenyon-Jones's study of Romantic animals, which turns on Byron's friendship with a bear and above all, with two Newfoundland dogs. Although residual ideas about animals persisted, such as the doctrine of signatures, and dominant ideas included a continuing faith in a beneficent providence structured around human superiority, it is the emergent idea "of a consubstantiality or confraternity between human beings and animals" that Kenyon-Jones finds "most important" in this period.[22]

David Perkins's Romanticism and Animal Rights makes the claim that what is distinctively Romantic is inherited from the enlightenment: a concatenation of "sympathy, sentiment, and nature," a "practical, reforming benevolence," and a "protest against cruelty to animals." [23] Perkins admits that he has adopted the phrase "'animal rights'" as "a shorthand term for kindly attitudes to animals and pleas for reform in the treatment of them" - thus conveniently by-passing intense debates within the world of animal activism and advocacy about the very nature, purchase, and potential effectiveness of a discourse of rights for improving the lives of animals.[24] 
Cruelty versus kindness serves as the organizing problematic upon which Perkins's study is constructed, and characterizes his own position within this problematic as admittedly contradictory. Perkins has "worked on a small farm" and "kept pets for years," yet "strongly" favors "kindness to animals, much more than exists at present."[25] This attitude puts him at odds vis-à-vis "Romantic authors," he claims, because they "generally assumed that the best thing for animals was to be far from humans, living their wild lives without interference."[26] This puts a new spin on the idea of animal rights - in which domestication is slavery, and animals should be "free" - as "Romantic," as deriving from the period of Romanticism and Romantic notions of ideal, noninterfering relations between mankind and the natural world.[27] Perkins's self-professedly contradictory compromise, by contrast to this Romantic pastoralism, might be described as a georgic idea of stewardship, in which human involvement with animals entails responsibility for their welfare.[28]

A certain complacency emanates from this work, which celebrates Romanticism, and indeed the unfolding of the enlightenment in its emancipatory guise, as the progress of kindness, of which we are inheritors. Erica Fudge's contribution to the conversation that closes Killing Animals rightly suggests that we be cautious about such teleological optimism. As Fudge remarks, and as the horrifying statistics about animal killing that open this 2006 book show, we are not kinder; we are just less openly and often reminded of how cruel we are.[29] Fudge observes in the conclusion of her own essay in Killing Animals that the whiggish imperative to write a teleological history of progress - in this case, the progress of kindness - is with us still, and that it continues to serve conservative ends: "There is, after all, nothing more reassuring than thinking that we are better humans than those men and women of the past. Nothing is more comforting than a history that allows us to maintain the status quo."[30]

New work on Romantic animals, then, remains in need of both a longer historical view, so that the newness of the new can be more finely particularized and not exaggerated, and a greater skepticism regarding the reach and purchase of the progress of kindness as a measurement of the European enlightenment 
inheritance that has been bequeathed to modernity as it is usually understood.

\section{Eastern Enlightenment, Ottoman History}

Perkins's book poses a further challenge for animal studies, one that might take us back to the Marx of "On the Jewish Question" and other critiques of formal equality. Despite his own investments in pet-keeping and smallholder husbandry, Perkins gives voice to a Romantic notion that all situations of inequality, such as obtain between homo sapiens and other species, must be unethical and even abusive: "A relationship cannot be morally healthy that is utterly unequal, the one dominant, the other helpless and vulnerable."[31] This statement begs several questions. Must physical proximity and close communication between humans and other species always result in exploitation? Can all relations between humans and other animals be adequately described as relations of arrogant dominance and abject subordination? Are ethical relationships only possible between equals? Given the hollowness of formal equality within Marx's and other materialist thinkers' political understanding, should equality remain a political desideratum, or should we be working towards alternative models for negotiating intractable differences of power, so often the hardest stones to push?

Here my second epigraph, from Steven Shapin's review of books on the English coffee house, points towards one alternative model of social and political negotiation of difference. The Ottoman empire was hardly a model of political equality. Yet certain institutions originating in the Ottoman domains may well have had a levelling or even democratising effect on the hierarchies of European societies, including Britain. Habermas's theory of the public sphere posits the London coffee house as the incubator of democratic political debate. The freedom to express political opinions regardless of one's social rank is the single most necessary freedom, according to Habermas, for the emergence of the modern political state. Concerning the emergent European institutions of Tischgesellschaften, salons, and coffee houses, Habermas argues that despite demographic differences, all these new gathering places had a number of levelling features in common: 
First, they preserved a kind of social intercourse that, far from presupposing the equality of status, disregarded status altogether. The tendency replaced the celebration of rank with a tact befitting equals. The parity on whose basis alone the authority of the better argument could assert itself against that of social hierarchy and in the end can carry the day meant, in the thought of the day, the parity of 'common humanity' ('bloss Menschliche'). Les hommes, private gentlemen, or die Privatleute made up the public not just in the sense that power and prestige of public office were held in suspense; economic dependencies also in principle had no influence. Laws of the market were suspended as were laws of the state. Not that this idea of the public was actually realized in earnest in the coffee houses, the salons, and the societies; but as an idea it had become institutionalized and thereby stated as an objective claim. If not realized, it was at least consequential.[32] As Habermas would have it, the coffee house became the site of an experience of "common humanity." The celebration of rank, with its displays of power and codes of deference, was replaced, Habermas insists, by "a tact befitting equals." The "power of the better argument," rather than the social or economic power of the gentleman who expressed it, became "institutionalized and thereby stated as an objective claim." If not "actually realized" in the coffee houses, especially not always "in earnest," the idea of a rational debate, based upon a parity of opinions rather than participants, became, according to Habermas, "at least consequential." It will not be long before the all-male and upperranks ethos of the coffee house will be challenged because of that very consequential idea of a contest of arguments not hemmed round by the social characteristics of their makers.

The public was expanded, informally at first, by the proliferation of press and propaganda; along with its social exclusiveness it also lost the coherence afforded by the institutions of sociability and a relatively high level of education. .. In this situation Mill observed how manual workers, women, and (in the United States) blacks pressed for the general franchise.[33]

Laborers, women, people of color: constituencies not belonging to the gentlemanly public gradually came to be interpellated by coffee house principles, and began agitating for access to such spaces of public opinion. 
Indeed it was the fear of the mixing of ranks, and the transgressing of boundaries of politeness, that caused coffee houses sometimes to be shut down in the name of preventing sedition, as happened in Britain during Charles's II's reign, or during moments of pious reform in the Ottoman empire. Yet the potential for sedition was often perceived by the authorities to be much in excess of the actual achievement of social parity or any material undermining of hierarchies of wealth and status. These contradictions animate the discourse of Addison and Steele's Tatler and Spectator. It is no accident that it is Eubulus, a man of independent fortune, whose coffee house opinions are the ones taken up and reproduced at less exalted London dinner tables. "He enjoys a great Fortune handsomely, without launching into Expence, and exerts many noble and useful Qualities, without appearing in any publick Employment," Steele observed.[34] Once Eubulus has issued a pronouncement, his imitators repeat it ad nauseum as if it were their own: "In a word, every Man is Eubulus as soon as his Back is turn'd."[35] Deference to the rich is thus represented as all too common amongst the English public. Eubulus's views may indeed be both reasonable and just, but the fact that he is a gentleman of private means appears inseparable from these Londoners' conception of the likelihood of such authority.

If the experience of parity or equality, that would, in spite of its illusory nature, prove consequential, was characteristic of the coffee house, it seems worth enquiring into the origins of the model of social life that brought it forth, since it clearly was not natively "English," given the evidence of the Spectator, whatever Habermas might have imagined. As Steve Shapin notices, with coffee and the coffee house, Europeans imported new forms of sociability from the Ottoman East:

Late $17^{\text {th }}$-century Londoners bought a dark, hot, bitter brew called coffee when they spent their penny at a coffee house, but they also bought forms of sociability that were explicitly, if eclectically, modelled on those of the coffee houses of Smyrna, Aleppo, Cairo and Constantinople. 'The Ottoman Origins of Modernity' might make Habermas swallow hard, but, follow his arguments about the London coffee house, and that's one place they lead.[36] 
What these forms of sociability were like is well described by Markman Ellis, based upon English travellers' accounts such as those by Henry Blount and William Biddulph, who also appear in Gerald MacLean's The Rise of Oriental Travel; Ottoman historians shed further light.[37]

From an animal studies perspective, Orhan Pamuk's Istanbul coffee house dog in the novel My Name Is Red is particularly worth attending to. The dog, who is both a real dog and the sketch of a dog belonging to a coffee house storyteller, argues against the puritanical views of a cleric from Erzurum who would shut the coffee houses down in the name of piety and order. The dog mimics the cleric as follows:

'Coffeehouses are places where pleasure-seekers and wealthy gad-abouts sit knee-to-knee, involving themselves in all sorts of vulgar behaviour; in fact, even before the dervish houses are closed, coffeehouses ought to be banned. . . Men frequent these places, become besotted with coffee and lose control of their mental faculties to the point that they actually listen to and believe what dogs and mongrels have to say.'[38]

Having taken the piss out of the cleric by ventriloquizing him, the dog then proceeds to demolish the piety of the Erzurumi's arguments, proclaiming that he, as a dog, is "a great admirer of our coffeehouses"[39] for precisely the same reasons the cleric despises them. Coffee houses encourage mixing and the mutual listening and learning amongst all sorts of men and mongrels. Political wisdom and improvements to social welfare, for dogs as well as poor men, are the consequence of this social mixing, and both these ideas are supported by Islam. The puritanical cleric, who cannot listen to a dog when he meets one, is therefore nothing less than a bad Muslim:

In the lands of the infidel Franks, the so-called Europeans, every dog has an owner. These poor animals are paraded on the streets with chains around their necks, they're fettered like the most miserable of slaves and dragged around in isolation. .. Dogs who roam the streets of Istanbul freely in packs and communities, the way we do, dogs who threaten people if necessary, ... such dogs are beyond the infidels' conception. . . It's not that I haven't thought that this might be why followers of the Erzurumi oppose praying for dogs and feeding them meat on the 
streets of Istanbul in exchange for divine favors and even why they oppose the establishment of charities that perform such services. If they intend both to treat us as enemies and make infidels of us, let me remind them that being an enemy to dogs and being an infidel are one and the same.[40]

This canine resident of the early modern Ottoman public sphere perceives certain cultural differences between East and West that may appear quite strange to a Western audience, hence defamiliarizing. The free and the unfree, the happy and the enslaved, appear reversed. This is why consorting with mongrels in coffee houses amounts to sedition, never a bad idea in political and philosophical discussions if we seek to pursue elusive truths.

This dog's eye view reveals above all how imbricated East/West and infidel/non-infidel remain, despite their differences, for all subjects poised on the frontier between Europe and Asia. European visitors frequently commented on the egalitarianism they observed in Ottoman society, despite differences of wealth. There was more public mixing of classes, professions, religions, and ethnicities, cultural identities, and nations or "races" than obtained in Europe during the seventeenth and eighteenth and even the nineteenth centuries. Even the gendered separations have been exaggerated by subsequent centuries, compared with what obtained in the eighteenth century. What underpinned this levelling was not an idea of formal equality but rather the skilful negotiating of difference.

Gerald MacLean explains how very different the idea of sovereignty was for Ottoman rulers as opposed to European ones. This meant that Ottoman diplomacy took different forms from European diplomacy. It also meant that religious toleration, charity and philanthropy or beneficence, and meritocracy were enshrined within the system in ways unimaginable in sixteenth or seventeenth-century Europe. MacLean observes:

Ottoman policy was consistently to install a form of discriminatory toleration based on the aman system of safe conduct; this permitted Jews and Christians of any and all denominations to continue practicing their own religions and trades so long as they accepted the authority of the Sultan, paid their taxes, obeyed local regulations, and did 
not cause trouble. . . Sultans viewed themselves as rulers of the whole world, not simply a limited region, and they consequently recognised no other leaders as their equals: reciprocity was not an option, submission was.[41] And yet that submission had to be achieved in ways that preserved the dignity of the sultan's subjects. If it was not reciprocity, exactly, it was a relation of power in which there were strict guidelines to be observed by the more powerful as well as the less powerful.

Rituals of negotiation of power by which submission might be achieved without humiliation or abjection are brilliantly characterised by the Ottoman historian Palmira Brummett, who explains the pratice of el öpmek - paying homage, kissing the Sultan's hand - as follows:

There was never a full expectation of obedience, and the parameters ... could be modified by factors such as the degree of intimacy (or affection) between the parties, the potential rewards of insubordination, and the calculations of the level of violence that each party could and could not mobilize or tolerate.[42]

These protocols, according to Brummett, "provided the ritual security that enabled parties with often widely divergent objectives to meet, negotiate on familiar rhetorical ground, and build relationships, whether those relationships were hostile or cordial. They served to avert violence as well as to symbolize its power. That familiarity, or universality, in rituals of submission, subverts the too-simple rhetorics of 'Europe' vs. 'Asia,' believer vs. infidel, and East vs. West."[43] Brummett, an American scholar, takes her cue regarding the richness and complexity of the signifying power of hand-kissing and other rituals of powernegotiation from J. E. Lighter's Historical Dictionary of American Slang:

Kiss, n. 1) a drink; 2) a blow

Kiss, v. 1) to flatter; Cf. kiss up

2) to strike (esp. a baseball) hard; to wallop

Kiss goodbye: to resign oneself to the loss of . . . usually used

Kiss off, $v$.

sarcastically

1) a. to reject, spurn, dismiss

b. to murder 

used

c. to dispose of casually, slight, disregard, ignore

2) to go away and stop giving annoyance; depart -- usually

imperatively

Kiss up, v. to curry favour, ingratiate oneself [44]

As Brummett comments, "There is, of course, an intimate connection between affection and submission, as these examples of American slang indicate. .. [T] [The association of the kiss with acts of submission, ingratiation, self-promotion, and dismissal is unmistakeable. Our own use of the word suggests an enduring connection between the kisses of the twenty-first century and the ritual acts and iconography of the Early Modern era" - and its Ottoman forms in particular.[45] Brummett's "enduring connection," I would like to emphasize here, is not one predictive of either the achievement or even the desirability of formal political equality.

This context sheds light on how, although there were certainly similarities and complicities which have been too often denied, Ottoman society was organized in some respects differently from western European societies, and offers an alternative model to English or British society's self-image. Overcoming differences in status was the object of the exercise. There was not so much a positing of an ideal, however unrealised, of formal equality, but a system for negotiating material differences in power. I am not so much recommending Ottoman conceptions of sovereignty, or a return to a culture of deference tout court, as suggesting the desirability of an ethics that does not depend upon the achievement or even the necessary ideal of formal political equality. Ethics and obligation, hospitality and responsibility, respect, tactfulness, and active charity, can be operative even when there are disparities in power, and when there is plenty of opportunity for abuse. This was one of the forms of enlightenment that European travellers encountered and were surprised by in the East, just as they were surprised that if animals, horses in particular, were treated kindly and rationally, they would respond in kind.

\section{Eastern Enlightenment, Equine History}

"Turkish equestrian tradition? Ten thousand years of ignorance," exclaimed an Australian veterinary consultant recently, speaking 
with all the confidence of being based in London and having clients in too many countries in Asia to name. Yet many early modern Western visitors to the lands ruled by the Ottomans thought differently. Once upon a time, at least, Western Europeans were so impressed by the arts and sciences of the Ottoman empire that they sought to imitate and appropriate them for themselves. The great Eastern empires were globally powerful economically as well as politically long before Europe could cut much of a figure on the world stage.[46] The attitude of superiority captured by Edward Said's notion of Orientalism as a discursive paradigm suited to colonial administration and bound up with imperial rule came only later, largely post-1798, after Bonaparte's invasion of Egypt.[47] During the preceding centuries, it would not be wrong to see glimmerings of enlightenment occurring precisely when Europeans looked East, as Gerald MacLean has observed. Awestruck by the splendour of the Ottoman court, and humbled by the sophistication of its rituals and protocols, European visitors often found themselves in situations of what MacLean calls "imperial envy."[48]

One highly influential account of the superiority of Ottoman horsemanship that signified beyond human-equine relationships towards something like a theory of Ottoman governance was Ogier Ghiselin de Busbecq's. Published in Latin in 1633, this account by the Habsburg ambassador to the Sublime Porte during the years between 1554 and 1562 was widely known on the Continent and in Britain. Fifty years after its publication, John Evelyn recalled Busbecq's observations in detail when first confronted with Ottoman horses in London in 1684, brought to Britain as spoils of war after the siege of Vienna. An English translation was published in 1744, so that Busbecq's ideas continued to be disseminated, retaining their currency years after his embassy to Istanbul.[49] The essence of Busbecq's observations is that Ottoman gentleness and indulgence in handling horses led to a greater partnership between humans and equines than had ever been achieved in Europe. "There is no Creature so gentle as a Turkish Horse; nor more respectful to his Master, or the Groom that dresses him. The reason is, because they treat their Horses with great Lenity," wrote Busbecq, concluding that this lenient regime made for willing working relationships: "This makes their Horses great Lovers of Mankind; and they are so far from kicking, wincing, or growing untractable 
by this gentle usage, that you shall hardly find a masterless Horse among them."[50] Busbecq described in detail:

how indulgent the Country-men were to young Colts, and how kindly they used them soon after they were foled; they would stroke them, bring them into their Parlours, and almost to their Tables, and use them even like Children. ... . [A]nd the Grooms, that are to dress them, are as indulgent as their Masters; they frequently sleek them down with their Hands, and never use any Cudgel to bang their Sides, but in case of great Necessity.[51]

Busbecq emphasises that kindly versus brutal treatment is not a matter of the difference in rank of the horses' handlers: both the masters, who are land-owning farmers, and their laboring-class servants, the grooms, are kind. The kindness takes the form of a great deal of human contact. From the time of foalhood onwards, Ottoman horses are stroked and handled with gentleness and affection. They may be brought indoors, showered with attention, indulged. They are indeed treated in an anthropomorphic way, as if they were children. But that projection of human-likeness upon the horses also presupposes that there is a degree of rationality, a potential for education, and the possibility of arriving at a mutual understanding that far exceeds customary European valuation of horses' mental capabilities. William Cavendish, remember, was having to argue against what he believed Descartes had argued, insisting from his own experience that horses were capable of thinking, learning, and remembering at all.

If disciplining and punishing were a last resort in this Ottoman regime of horsemanship, they were clearly the first resort in the European one. Busbecq appears to have thought that big sticks and whips were the most common implements employed by European grooms:

But, alas! our Christian Grooms treat Horses at quite another rate; they never think them rightly curried, till they thunder at them with their Voice, and let their Club or Horse-whip, dwell, as it were, on their Sides. This makes some Horses even to tremble when their Keepers come into the Stable, so that they hate and fear them too: But the Turks love to have their Horses very gentle, that, at a word of Command, they may fall down on their Knees, and in this Posture receive their Riders.[52] 
With antagonism between humans and horses the common European currency in their dealings, European grooms and horsekeepers, according to Busbecq, routinely behaved like brutes. They attempted to make horses terrified and to gain obedience through violence or its threatened appearance at the least sign of resistance. Consequently, horses learned both to hate and fear human authority in the European system. The Ottoman system, on the other hand, theoretically at least, induced obedience not through harsh treatment or fear but through affection and love, through achieving a strong bond between horse and rider or horse-coper.

The question of governability, and the fear of the ungovernable, haunt Busbecq's writing about horsemanship and horse-keeping. Masterless horses, like masterless men, could threaten the social order. But how best to achieve mastery in order to harness vital horse-power for human use? The image of the horse who kneels to enable the rider to mount with ease may strike modern readers as an image of egregious subservience. For Busbecq, however, this kneeling at a word of command is a sign of gentleness, of a thorough education in human requirements. Might we go further and suggest that it is a sign of civility and even of gentility, of a willingness to serve? Busbecq does not say exactly how this behavior has been taught to the horses. But his whole description of Ottoman horsemanship emphasises teaching by encouragement, with patience, with "indulgence," and not with shows of force. Sympathetic, and even loving, working with, rather than beating into submission, appears to have been what produced this willingness to bow, serve, wish to please. Busbecq stresses that the partnership between Ottoman horsemen and their horses has not been achieved by human domination or coercion, but by a lenient, kindly, respectful attitude to the horses themselves, based on a loving understanding of their requirements.

As a consequence of a very different regimen of human-animal relations, then, the horses of the Ottoman empire appeared quite different from European horses. When John Evelyn saw Ottoman horses for the first time in December 1684, in St. James's Park, he thought immediately of Busbecq and how well the horses behaved as a result of their upbringing, as well as how beautiful they were: 
\& with my Eyes never did I behold so delicate a Creature as was one of them, of somwhat a bright bay, two white feete, a blaze; such an head, [Eye,] eares, neck, breast, belly, buttock, Gaskins, leggs, pasterns, \& feete in all reguards beautifull \& proportion'd to admiration, spiritous \& prowd, nimble, making halt, turning with that sweiftnesse $\&$ in so small a compase as was incomparable, with all this so gentle $\&$ tractable, as called to mind what I remember Busbequius speakes of them; to the reproch of our Groomes in Europ who bring them up so churlishly, as makes our horse most of them to retaine so many ill habits $\& c$ : They trotted like Does, as if they did not feele the Ground; for this first Creature was demanded 500 Ginnies, for the $2 \mathrm{~d} 300$, which was of a brighter bay, for the $3 \mathrm{~d} 200$ pound, which was browne, all of them choicely shaped, but not altogether so perfect as the first. In a word, it was judg'd by the Spectators, (among whom was the King, Prince of Denmark, the Duke of Yorke, and severall of the Court Noble persons skilled in Horses, especially Monsieur Faubert \& his sonn \& Prevost, Masters of the Accademie and esteemed of the best in Europe), that there were never seene any horses in these parts, to be compared with them.[53]

Evelyn's admiration of the superiority of these Ottoman horses and the kind of handling they represent is paradigmatic of many western accounts. MacLean's idea of "imperial envy" helps us to grasp the combination of covetousness, emulation, awe, and discomfiture with the inferiority of European arrangements and their outcomes that is so apparent in this passage. The beauty and delicacy of the horses is matched by their athleticism. The spiritedness of the horses is accompanied not by resistance or bad manners, but by their opposite. "Spiritous \& prowd," the horses, seized from an Ottoman general or paşa, are also "so gentle \& tractable" that Evelyn can hardly believe his eyes. These are not the sort of cavalry horses his European experience has led him to expect. He must have recourse to Busbecq's description of the Ottoman horses of the previous century in order to begin to comprehend what he is seeing, to account for its existence on English soil.

The unasked question is whether these horses will succeed in influencing their new owners and handlers to treat them as they 
are accustomed to being treated. Will the horses be able to effect some changes in horse-keeping practice by their behaviour and example? Or will the horses suffer the consequences of being at the sharp end of cultural difference, having to endure being manhandled in the usual brutalising European manner? Evelyn cannot tell us the outcome, but his discourse here resonates with discussions of the measurement of the progress of enlightenment. If kindness versus cruelty might constitute a sign of greater civility and even of superior civilisation, then there is still something to be learned from the East..

\section{Towards a Creaturely Ethics}

When Thomas Smith, "B.D. and Fellow of St Mary Magdalen College Oxon," visited the Ottoman empire in the 1670s, he was struck by two things: that the "Turks" did indeed deserve to be labelled a "Barbarous Nation," as they often were by western Europeans, and that they were "excessively" kind to animals.[54] Smith thought that Ottoman society was barbarous, however, not because it was uncivilized - on the contrary, he found the Turks amongst themselves to be a most civil, disciplined, and respectful people - but because as a nation they considered themselves so superior to everybody else. It was "the intolerable Pride and Scorn wherewith they treat all the World besides" that really irked him. This indignation at Ottoman superiority was doubly infuriating to Smith because he could not understand why it was combined with such seemingly strong feeling for animals. "I found the Turks excessively pitiful and good natured towards dumb creatures, soon putting them out of their pain, if they were necessitated to kill them," he remarked.[55] And yet it was even more astonishing to Smith that when the plague came, and it was known that the street dogs of the city might be helping to spread it, the chief religious leader of Istanbul forbade killing these dogs, and had them transported across the Bosphorus to Üsküdar instead: "the Mufti . . . would by no means give way to so bloody and cruel a sentence, maintaining that it was unlawful; and that he might not seem to be peremptory without cause, he added this momentous reason, that Dogs had Souls, and therefore were to be exempt from this universal and horrid carnage."[56] Needless to say, Smith thought the idea of canine souls ludicrous in the extreme. It does not seem to have occurred 
to him that the sense of social and spiritual superiority enjoyed by Ottoman Muslims might be connected with their regard for their fellow creatures, even the "dumb" brutes, expressed in both everyday courtesies and pious pronouncements.

Animal killing has long served as a kind of litmus-test for attitudes towards animals. Today's animal rights activists, vegans, and other advocates for animals as deserving of equal treatment because they are sentient beings, argue against the killing of animals as an ethical principle. Other animal studies scholars take a different view. "[A]ll human relations with animals end with killing them," Garry Marvin, of the British Animal Studies Group, observes.[57] His views appear at odds with most of the other group members, whose contributions stress the ethical problems with killing animals while amassing horrendous statistics about such killing. Donna Haraway, however, is in fundamental agreement with Marvin, arguing that: "The problem is to learn to live responsibly within the multiplicitous necessity and labor of killing, so as to be in the open, in quest of the capacity to respond in relentless historical, nonteleological, multispecies contingency. . . [H]uman beings must learn to kill responsibly."[58] Learning and unlearning, in order to live responsibly with, and yet also, when necessary, kill responsibly, means for Haraway jettisoning what she elsewhere calls "puritanical critique." By puritanical critique, Haraway means critique of the kind that "indulge[s] in historical structural analysis in a way that denies both emotional bonds and material complexity and so avoids the always messy participation in action that might improve lives across many kinds of difference."[59] Messy participation is what Haraway most enthusiastically endorses, including getting down and dirty with her dogs by training with them.

Training, like killing, involves messy participation in animal worlds, and responsible participation requires attending to others whose views may be difficult to interpret. At the end of Killing Animals, the art historian Diana Donald remarks, "It seems to me we've skirted the fact that it's quite impossible to enter into animal subjectivity or to express things from an animal's point of view. But we've tried, haven't we?"[60] The group's final statement on what they have attempted to do is Robert McKay's; he comments that they have tried to "make the animal available 
for thinking about: to make it morally and intellectually visible and to make the obfuscations in much thinking about animals available for thinking about."[61] There is some slippage here between "the animal" - a philosophical trope - and "animals," in all their sentient and sensuous and social species being, all their vital multiplicity.

I agree with Garry Marvin that cultural specificity is more compelling than a generalized philosophical concern with "the animal," and that we need to interrogate the significance of the various "social, cultural, economic, political and environmental contexts" that gave shape to particular relationships between humans and animals, and to particular representations of animals, in specific times and places.[62] This specific kind of investigation and interrogation is what I have tried to do in the book Noble Brutes and also in this essay. Horses are a specific species and also individuated among themselves. They are not just or any "animals," let alone the philosophical trope "the animal." Marvin attempts to "puzzle through the complex feedback systems" looping between "representations and constructions that create the conditions or contexts for relationships with embodied animals in the world" and "the relationships themselves that create or generate representations which then create ... . Relationships out of representations, representations out of relationships."[63] He concludes that such "feedback systems are not, however, timeless, fixed or mechanical, and it is necessary to consider carefully how and why both social, economic, political and cultural changes within human societies, and the continuities and changes of how animals behave in their world, give rise to new representations and relations."[64]

The training of and with animals, working them and with them, is, like killing them, a human imposition of will and desire on beings whose own will and desire presents a conundrum for human interpreters. The risk of anthropomorphism, to say nothing of human opportunism, is unavoidable. And the training situation poses, as I have already suggested, certain ethical difficulties that resonate with the model of Ottoman governance marked by a tension between submission and leniency, absolute sovereignty and mutual courtesy, in which power is synonymous 
with obligation and social responsibility. As Paul Patton puts it, what human-animal training reveals most profoundly is that:

Disciplinary relations of command and obedience are precisely a means to create and maintain stable and civil relations between different kinds of beings, not only among individuals of the same species, but also between representatives of different species. . . The philosophical interest of this claim emerges when we consider that philosophers such as Nietzsche and Foucault are widely condemned for their insistence that all human social relations are power relations, in part on the grounds that if this were true it would amount to a denial of the possibility of ethical relations. The assumption here is that justice, fair treatment, and respect for others are possible only outside of or apart from relations of power. Power relations are relations of inequality, whereas the presumption of contemporary political theory is the moral equality of all the parties concerned. . . By contrast, what we learn from the disciplines of animal training is that hierarchical forms of society between unequals are by no means incompatible with ethical relations and obligations toward other beings.[65]

What the training situation demonstrates, then, according to Patton, is that "hierarchical forms of society between unequals are by no means incompatible with ethical relations and obligations toward other beings."[66] Like Haraway, Patton recognizes that attentive responsibility in action, rather than the hope of any possible purity of action, should guide us in our dealings with those for whom our privileges add up to a fundamental asymmetry of power.

If Marx in "On the Jewish Question" rejected the demand for formal political equality as an insufficiently materialist compromise that diverted political energies from working against the economic and social inequalities that would need to be overcome for the achievement of general emancipation, he was taking the long-term view.[67] The unfolding of enlightenment as the unfolding of general emancipation surely remains a worthy goal, articulated now as not merely human emancipation but creaturely emancipation. Such a horizon of possibility should continue to determine our ethical vision, in the long-term. As Gayatri Spivak, mindful of Derrida, has said, "Please note that I 
am not saying that ethics are impossible, but rather than ethics is an experience of the impossible."[68] Creaturely emancipation remains a horizon of possibility, however impossible simply to declare and bring into being. In the shorter-term, the time of acting in the now, willy-nilly, at least an openness to an ethics of responsibility, leniency, and a willingness to enter into mutual respect and service, despite differences of power, would seem to be more than ever necessary. Caroline Rooney, in asking again, "What is Enlightenment?," suggests: "[T]his being of service to the other is able to free itself from the indignity of the masterslave relation - a relation anti-colonial thinkers such as Albert Memmi insist is an indignity for the master at least as much as for the slave - through fellow feeling. We find our dignity - the dignity Kant seems to seek against the instrumentalising of ourselves - in being willingly of service to others."[69] Rooney calls this form of freedom an "alter-autonomy."[70] The Ottoman Islamic origins of modernity, and of creaturely responsibility, might make us, like Habermas, swallow hard, but follow the arguments attendant upon Eastern equines, those noble brutes, and that's one place they lead. 
My thanks to Angela McRobbie and Lisa Atkins for organising 'The Feminist and Cultural Politics of Creaturely Life', 27 February 2009, at Goldsmiths, University of London, at which I was able to deliver a version of this essay as a keynote. I am grateful to all the participants and audience members for their questions and suggestions.

\section{Notes}

[1] Caroline Rooney, Decolonising Gender: Literature and a Poetics of the Real (London and New York: Routledge/Taylor and Francis Group, 2007), 44-74.

[2] Donna J. Haraway, When Species Meet (Minneapolis and London: University of Minnesota Press, 2008), 222.

[3] Haraway, When Species Meet, 223.

[4] Gayatri Chakravorty Spivak, "Foucault and Najibullah," in Kathleen L. Komer and Ross Shideler, eds., Lyrical Symbols and Narrative Transformations: Essays in Honor of Ralph Freedman (Columbia, SC: Camden House, 1998), 218-35; this passage 219; reprinted in Other Asias (New York and London: Routledge, 2007), 132-60.

[5] To name but a few: Donna Haraway, The Companion Species Manifesto: Dogs, People, and Significant Otherness (Chicago:

Prickly Paradigm Press, 2003) and, more recently, When Species Meet; Vicki Hearne, Adam's Task: Calling Animals by Name (New York: Vintage/Random House, 1987); Susan McHugh, Dog (London: Reaktion, 2004); Erica Fudge, Pets (Stocksfield:

Acumen, 2008), and Brute Reasoning: Animals, Rationality, and Humanity in Early Modern England (Ithaca, NY and London: 
Cornell University Press, 2006); Barbara Smuts, "Reflections," in J. M. Coetzee, with Marjorie Garber, Peter Singer, Wendy Doniger, and Barbara Smuts, Amy Gutmann, ed., The Lives of Animals (Princeton, NJ: Princeton University Press, 1999), 107-20;

Elizabeth Marshall Thomas, The Hidden Life of Dogs (London: Orion, 2003); Ian Wedde, "Walking the Dog," in Making Ends Meet (Wellington, New Zealand: Victoria University Press, 2005).

[6] Ann Game, "Riding: Embodying the Centaur," Body and Society 7:4 (2001): 1-12; this passage 1.

[7] Game, "Embodying the Centaur," 1.

[8] Lisa Blackman, The Body: The Key Concepts (Oxford and New York: Berg, 2008), 8-9, 38-41, 119-20, 132. See Vinciane Despret, "The Body We Care For: Figures of Anthropo-zoo-genesis," Body and Society 10 (2-3) (2004): 111-34.

[9] Jonathan Burt, in "Conclusion: A Conversation," The Animal Studies Group, Killing Animals (Urbana and Chicago: University of Illinois Press, 2006), 188-209; this passage 199. For a another example of what my colleague Jonathan Flatley has described as "socialist horse studies," see Landry, "Settlers on the Edge, or Sedentary Nomads: Andrei Platonov and Steppe History," in Jonathan Lamb,.ed., Reenactment History, Volume 2: Settlers and Creoles (Houndmills, Basingstoke and New York: Palgrave, forthcoming).

[10] Sir Philip Sidney, An Apologie For Poetrie, Evelyn S. Shuckburgh, ed. (Cambridge: Cambridge University Press, 1905), 66.

[11] See Erica Fudge, "A Reasonable Animal?," in Brute Reasoning, 123-46, and "Two Ethics: Killing Animals in the Past and the Present," in Killing Animals, 99-119; Karen L. Raber, "'Reasonable Creatures': William Cavendish and the Art of Dressage," in Patricia Fumerton and Simon Hunt, eds., Renaissance Culture and the Everyday (Philadelphia: University of Pennsylvania Press, 1999), 42-66.

[12] I quote from the English translation of Cavendish's French treatise of 1658, Methode Et Invention Nouvelle de dresser Les 
Chevaux par le tres-noble, haut, et tres-puissant Prince Guillaume Marquis Et Comte De Newcastle . . . (Antwerp: Jacques Van Meurs, 1658), which appeared in 1743, as A General System of Horsemanship in all it's Branches: containing a Faithful Translation Of that most noble and useful Work of his Grace, William Cavendish, Duke of Newcastle, entitled The manner of Feeding, Dressing, and Training of Horses for the Great Saddle, and Fitting them for the Service of the Field in Time of War, or for the Exercise and Improvement of Gentlemen in the Academy at home: A Science peculiarly necessary throughout all Europe, and which has hitherto been so much neglected, or discouraged in England, that young Gentlemen have been obliged to have recourse to foreign Nations for this Part of their Education, 2 vols. (London: Printed for J. Brindley, 1743), 1: 12. Only the first volume is in fact Cavendish's work; the second is a translation of Gasper de Saunier.

[13] Margaret, Duchess of Newcastle, The Life of the Thrice Noble, High and Puissant William Cavendishe, Duke, Marquess, and Earl of Newcastle (London: Printed by A. Maxwell, 1667), Book 2: 67.

[14] Thomas Bedingfield, The Art of Riding, conteining diverse necessarie instructions, demonstrations, helps, and corrections apperteining to horssemanship, not heretofore expressed by anie other Author: Written at large in the Italian toong, by Maister Claudio Corte, a man most excellent in this Art (London: Henrie Denham, 1584), 95, 112.

[15] Captain Lewis Edward Nolan, Cavalry; Its History and Tactics (London: Thomas Brown, 1853), 141.

[16] Landry, Noble Brutes: How Eastern Horses Transformed English Culture (Baltimore, MD and London: The Johns Hopkins University Press, 2008), 126-28, 139-40, 161-63.

[17] Robert Markley's The Far East and the English Imagination, 1600-1730 (Cambridge and New York: Cambridge University Press, 2006) presents an alternative but also complementary view to my focus on the importance of the Ottoman Empire. 
[18] See, especially, Nabil Matar, Islam in Britain 1558-1685

(Cambridge and New York: Cambridge University Press, 1998); Lisa Jardine, Worldly Goods: A New History of the Renaissance (London and Basingstoke: Macmillan, 1996); Lisa Jardine and Jerry Brotton, Global Interests: Renaissance Art between East and West (London: Reaktion and Ithaca, NY: Cornell University Press, 2000); Gerald MacLean, ed., Re-Orienting the Renaissance: Cultural Exchanges with the East (Houndmills, Basingstoke and New York: Palgrave Macmillan, 2005), and MacLean, The Rise of Oriental Travel: English Visitors to the Ottoman Empire, 1580-1720 (Houndmills, Basingstoke and New York: Palgrave Macmillan, 2004); Daniel Vitkus, Turning Turk: English Theater and the Multicultural Mediterranean, 1570-1630 (New York and Houndmills, Basingstoke: Palgrave Macmillan, 2003); Matthew Dimmock, New Turkes: Dramatizing Islam and the Ottomans in Early Modern England (Aldershot, Hants and Burlington, VT: Ashgate, 2005), and Dimmock, ed., William Percy's Mahomet and His Heaven: A Critical Edition (Aldershot, HANTS: Ashgate, 2006; Matthew Birchwood, Staging Islam in England: Drama and Culture, 1640-1685, Boydell and Brewer Studies in Renaissance Literature 21 (Cambridge: D. S. Brewer, 2007), and Birchwood, "Vindicating the Prophet: Universal Monarchy and Henry Stubbe's Biography of Mohammad," in Elaine Hobby, ed., 'Prose of the Long Restoration,' a special issue, Prose Studies: History, Theory, Criticism 29: 1 (April 2007): 59-72. Important Ottomanist studies include Gülru Necipoğlu, "Süleyman the Magnificent and the Representation of Power in the Context of Ottoman-Hapsburg-Papal Rivalry," Art Bulletin 71 (1989): 401-27; Michael Rogers, "The Arts under Süleyman the Magnificent," in Halil İnalcık and Cemal Kafadar, eds., Süleyman the Second and His Time (Istanbul: Isis Press, 1993), 287-324; Amy Singer, Constructing Ottoman Beneficence: An Imperial Soup Kitchen in Jerusalem (Albany, NY: State University of New York Press, 2002). Other specialist studies of interest include Michael Bonner, Mine Ener, and Amy Singer, eds., Poverty and Charity in Middle Eastern Contexts (Albany, NY: State University of New York Press, 2003); Deborah Howard, Venice and the East (New Haven, CT: Yale University Press, 2000); and Julian Raby, Venice, Dürer and the Oriental Mode (London: Islamic Art Publications, 1982).

[19] Landry, Noble Brutes, 8-9, 133-36. 
[20] Ingrid H. Tague, "Dead Pets: Satire and Sentiment in British Elegies and Epitaphs for Animals," Eighteenth-Century Studies 41: 3 (Spring 2008): 289-306; this passage 301.

[21] Tague, "Dead Pets," 301.

[22] Christine Kenyon-Jones, Kindred Brutes: Animals in Romantic-period Writing (Aldershot, UK and Burlington, VT: Ashgate, 2001), 206.

[23] David Perkins, Romanticism and Animal Rights (Cambridge, UK and New York: Cambridge University Press, 2003), ix.

[24] Perkins, Romanticism and Animal Rights, x. The classic defence of animal rights is Tom Regan, The Case for Animal Rights (Berkeley and Los Angeles: University of California Press, 1983); the classic challenge to the notion of rights comes from Peter Singer, Animal Liberation; 2nd edn. (1975; New York: New York Review Books, 1990). For an update on this debate, see Coetzee with Garber, Singer, Doniger, Smuts, Gutmann, ed., Lives of Animals.

[25] Perkins, Romanticism and Animal Rights, xi, xii.

[26] Perkins, Romanticism and Animal Rights, xi.

[27] See Michael McKeon on the contradiction between "the dream of a direct apprehension of nature" and "the inevitability of nature's imaginative construction" in "The Pastoral Revolution", Kevin Sharpe and Steven N. Zwicker, eds., Refiguring Revolutions: Aesthetics and Politics from the English Revolution to the Romantic Revolution (Berkeley, Los Angeles, London: University of California Press, 1998), 267-89; this passage 289.

[28] Landry, "Georgic Ecology," in Simon White, John Goodridge, and Bridget Keegan, eds., Robert Bloomfield: Lyric, Class, and the Romantic Canon (Bucknell University Press, 2006), 253-68.

[29] Fudge, in "Conversation," Killing Animals, 202. 
[30] Fudge, "Two Ethics," 116.

[31] Perkins, Romanticism and Animal Rights, xii.

[32] Jürgen Habermas, The Structural Transformation of the Public Sphere: An Inquiry into a Category of Bourgeois Society, Thomas Burger, trans., with the assistance of Frederick Lawrence (1962; Cambridge: Polity, 1989; rpt. 2005), 36.

[33] Habermas, Public Sphere, 131-32.

[34] Richard Steele, The Spectator No. 49, Thursday, 26 April 1711, in Donald F. Bond, ed., The Spectator, 5 vols. (Oxford: Clarendon, 1965), 1: 210-11; this passage 210.

[35] Steele, Spectator 49, 211.

[36] Steven Shapin, 'At the Amsterdam', London Review of Books (28:8), 20 April 2006, 12-14; this passage 14.

[37] Markman Ellis, The Coffee House: A Cultural History (London: Weidenfeld \& Nicolson, 2004); MacLean, Rise of Oriental Travel; Brian Cowan, The Social Life of Coffee: The Emergence of the British Coffeehouse (New Haven and London: Yale University Press, 2005); Ralph S. Hattox, Coffee and Coffeehouses: The Origins of a Social Beverage in the Medieval Near East, $3^{\text {rd }}$ printing (1985; Seattle and London: University of Washington Press, 1996); Edward Robinson, The Early English Coffee House (1893; Christchurch, Hants: The Dolphin Press, 1972); Caroline Finkel, Osman's Dream: The Story of the Ottoman Empire (London: John Murray, 2005); Shirine Hamadeh, The City's Pleasures: Istanbul in the eighteenth Century (Seattle and London: University of Washington Press, 2007); Dana Sajdi, ed., Ottoman Tulips, Ottoman Coffee: Leisure and Lifestyle in the Eighteenth Century (London and New York: Tauris Academic Studies, 2007). Charles II tried briefly in December 1675 to shut down the coffee houses. They had become places in which the king's scandalous sex life and his failure to produce a legitimate heir were too freely discussed in ways that might constitute sedition. As James Grantham Turner wryly observes, Charles was concerned that "his private parts had been in everybody's mouth"; "Pepys and the Private Parts of Monarchy," in Gerald 
MacLean, ed., Culture and Society in the Stuart Restoration: Literature, Drama, History (Cambridge and New York: Cambridge University Press, 1995), 95-110; this passage 104. The effort was quickly abandoned, so committed were Londoners to their coffee and to the association between coffee houses and free speech; see Ellis, Coffee House, 86-105.

[38] Orhan Pamuk, 'Chapter 3: I Am a Dog', My Name Is Red [Benim Adım Kırmızı], Erdağ M. Göknar, trans. (New York: Alfred a. Knopf, 2001), 10-15; this passage 12.

[39] Pamuk, Red, 13.

[40] Pamuk, Red, 14.

[41] Gerald MacLean, "Courting the Porte," paper delivered at University of York, 15 November 2006, and Nottingham Trent University, 5 December 2006; citing Palmira Brummett [see below], and A. Nuri Yurdusev, ed., "The Ottoman Attitude toward Diplomacy," Ottoman Diplomacy: Conventional or Unconventional? (Houndmills, Basingstoke: Palgrave, 2004), 535; esp. 15-20.

[42] Palmira Brummett, "A Kiss is Just a Kiss: Rituals of Submission Along the East-West Divide," in Matthew Birchwood and Matthew Dimmock, eds., Cultural Encounters Between East and West, 1453-1699 (Newcastle-upon-Tyne: Cambridge Scholars Press, 2005), 107-31; this passage 116.

[43] Brummett, "Kiss," 124.

[44] Brummett, "Kiss," 107, citing J. E. Lighter, The Random House Historical Dictionary of American Slang, vol. 2 (New York: Random House, 1997), 364-66.

[45] Brummett, "Kiss," 107.

[46] See, especially, K. N. Chauduri, Asia before Europe:

Economy and Civilisation of the Indian Ocean from the rise of Islam to 1750 (Cambridge and New York: Cambridge University Press, 1990) and Trade and Civilisation in the Indian Ocean: An Economic History from the Rise of Islam to 1750 (Cambridge and 
New York: Cambridge University Press, 1985); Andre Gunder Frank, ReOrient: Global Economy in the Asian Age (Berkeley, Los Angeles, London: University of California Press, 1998); and Kenneth Pomeranz and Steven Topik, The World that Trade Created: Society, Culture, and the World Economy 1400-the Present (Armonk, NY and London: M. E. Sharpe, 1999).

[47] Edward W. Said, Orientalism (1978; London and New York: Penguin, 1995).

[48] Gerald MacLean, Looking East: English Writing and the Ottoman Empire before 1800 (Houndmills, Basingstoke and New York: Palgrave Macmillan, 2007), 20-23, 189-98.

[49] Ogier Ghiselin de Busbecq, Travels into Turkey: Containing the most accurate Account of the Turks, and Neighbouring Nations, Their Manners, Customs, Religion, Superstition, Policy, Riches, Coins, \&c. The whole being a series of remarkable observations and events, interspers'd with great variety of entertaining incidents, never before printed, Translated from the Original Latin of the Learned A. G. Busbequius, With Memoirs of the Life of the Illustrious Author (London: Printed for J. Robinson; and W. Payne, 1744), and Edward Seymour Forster, ed., The Turkish Letters of Ogier Ghiselin de Busbecq, Imperial Ambassador at Constantinople 1554-1562, Newly Translated from the Latin of the Elzevir Edition of 1633 (Oxford: Clarendon Press, 1927).

[50] I have quoted from the eighteenth-century English translation. Busbecq, Travels, 131-32.

[51] Busbecq, Travels, 131-32.

[52] Busbecq, Travels, 131-32.

[53] John Evelyn, Kalendarium 1673-1689: The Diary of John Evelyn, E. S. deBeer, ed., 6 vols. (Oxford: Clarendon Press, 1955), 4: 398-99.

[54] Thomas Smith, Remarks Upon the Manners, Religion And Government Of the Turks. Together with A Survey of the Seven Churches Of Asia, As they now lye in their Ruines: And A Brief 
Description of Constantinople (London: Printed for Moses Pitt, 1678), 1, 103.

[55] Smith, Remarks, 2, 103.

[56] Smith, Remarks, 106.

[57] Garry Marvin, in “Conversation," Killing Animals, 189.

[58] Haraway, When Species Meet, 80, 81.

[59] Haraway, Companion Species Manifesto, 89-90.

[60] Diana Donald, in “Conversation," Killing Animals, 209.

[61] Robert McKay, in "Conversation," Killing Animals, 209.

[62] Garry Marvin, "Wolves in Sheep's and Other Clothing," revised version of a paper originally delivered at the German Historical Institute conference on "Looking at Animals," May 2005, 9; "Wölfe in Schafs und anderen Pelzen," in Dorothee Brantz and Christof Mauch, eds., Tiere in der Geschichte (Paderborn: Schöningh, 2007). My thanks to Marvin for letting me read the English version in typescript.

[63] Marvin, “Wolves," 10.

[64] Marvin, "Wolves," 10.

[65] Paul Patton, "Language, Power, and the Training of Horses," in Cary Wolfe, ed., Zoontologies: The Question of the Animal (Minneapolis and London: University of Minnesota Press, 2003), 83-99; this passage 95-96.

[66] Patton, "Language, Power," 95.

[67] Karl Marx, "On the Jewish Question," in Robert C. Tucker, ed., The Marx-Engels Reader, $2^{\text {nd }}$ edn (New York and London: W. W. Norton, 1978), 26-52.

[68] Gayatri Chakravorty Spivak, "Translator's Preface and Afterword to Mahasweta Devi, Imaginary Maps," in Donna Landry 
and Gerald MacLean, eds., The Spivak Reader (New York and London: Routledge, 1996), 267-86; this passage 270.

[69] Rooney, Decolonising Gender, 73-74.

[70] Rooney, Decolonising Gender, 74. Rooney concludes: "Ultimately, there's no such thing as self-emancipation. There's only socialism" (74). 